\section{På tide at noen forklarer hva sakprosa er}

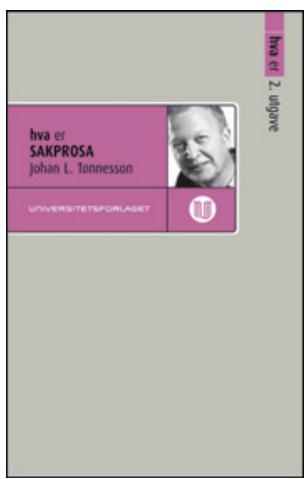

Johan L. Tønnesson

Hva er sakprosa

2. utg. 160 s. Oslo: Universitetsforlaget, 2012

Pris NOK 179

ISBN 978-82-15-01945-1

Norges første professor i sakprosa, Johan L. Tønnesson, har skrevet sitt fag. Denne inngår i Universitetsforlagets Hva er-serie, der «Norges fremste fagformidlere» skal gi svar på krevende spørsmål. Hittil er det kommet 47 bøker, flere av dem er blitt anmeldt i Tidsskriftet (1-7).

Dette er andre utgave. Førsteutgaven kom i 2008. Jeg har ikke lest den, og det fremgår heller ikke hvorfor det er behov for en ny utgave bare fire år etter. Er sakprosa et felt i rivende utvikling? Det skjer i hvert fall en del. Stortinget innførte i 2005 en egen innkjøpsordning for sakprosa, slik at et visst antall nye utvalgte bøker hvert år skal finnes på alle landets folkebiblioteker. Samme år ble det opprettet et eget professorat i faget ved Universitetet i Oslo, i 2011 også i Bergen, og på universiteter og høyskoler står det på pensum. I 2007 fikk den litterære Brageprisen en hovedklasse for sakprosa. Blant myndigheter og næringsliv øker bevisstheten om at det for en stor del er sakprosaen vi lever av her i landet - ved siden av fisken og oljen, som forfatteren uttrykker det. Feilskjær i sakprosaen kan bety tap av kunder, kontrakter og kunnskap.

Det er på høy tid at noen forklarer hva sakprosa er. Det er ambisjonen med boken, skriver forfatteren. De fleste tenker vel på sakprosa som bøker og tidsskrifter, men Tønnesson argumenterer for at begrepet rommer mye mer: brosjyrer, stemmesedler, stortingsmeldinger, e-poster, regnskaper, bruksanvisninger, blogger osv. Merkelig nok finnes begrepet «sakprosa» kun i nordiske språk. Like pussig er det at sakprosaen alltid har levd et liv i skyggen av den skjønne litteraturen, slik det fremgår av de tradisjonelle litteraturhistoriene.

Særtrekk ved medisinsk sakprosa presenteres gjennom et intervju med Tidsskriftets tidligere redaktør Magne Nylenna. Før gjaldt «publish or perish»-publiser eller forsvinn. Etter at antall fagartikler er blitt stadig viktigere for å få penger til videre forskning, er følgende spørsmål blitt presserende blant mange: «publish your rubbish».

\section{Erlend Hem}

Tidsskriftet

\footnotetext{
Litteratur

Kirkengen AL. Hvem og hva er kropp? Anmeldelse av: Engelsrud G. Hva er kropp. Tidsskr Nor Lægeforen 2007; 127: 930

2. Holtedahl KA. Kort og meget godt om hva vi driver med. Anmeldelse av: Schei E. Hva er medisin. Tidsskr Nor Lægeforen 2007; 127: 3288.

3. Helstrup T. Godt om hukommelse. Anmeldelse av: Karlsen PJ. Hva er hukommelse. Tidsskr Nor Legeforen 2009: 129: 669-70.

4. Bjelland I. Ujevnt om angst. Anmeldelse av: Moxnes P. Hva er angst. Tidsskr Nor Legeforen 2010; 130: 857.

5. Getz L. Godt og elegant om helse. Anmeldelse av: Mæland JG. Hva er helse. Tidsskr Nor Legeforen 2010; 130: 2043.

6. Conradi S, Rand-Hendriksen S. Funksjonshemning fra mange synsvinkler Anmeldelse av: Tøssebro J. Hva er funksjonshemming. Tidsskr Nor Legeforen 2011; 131: 1213

7. Vandvik IH. Smerte - et komplisert tema. Anmeldelse av: Fors EA. Hva er smerte. Tidsskr Nor Legeforen 2013; 133: 1090.
}

\section{Like rettigheter, ulike muligheter?}

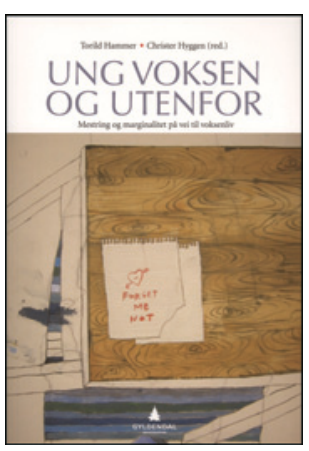

Torild Hammer, Christer Hyggen Ung voksen og utenfor

Mestring og marginalitet på vei til voksenlivet. 239 s, tab, ill. Oslo: Gyldendal Akademisk, 2013. Pris NOK 325

ISBN 978-82-05-43644-2

Gjennom de siste årene har det vært økt oppmerksomhet på perioden mellom ungdomstid og voksenliv, ung voksen-perioden. Begrepet omfatter vanligvis aldersspennet fra slutten av tenårene til slutten av 20-årene, men for mange vil det være en livsfase som strekker seg et tiår lenger. Det er spesielt de sosiale forandringene som preger denne livsfasen. En viss grad av selvstendighet og økonomisk frihet kombinert med lite økonomiske forpliktelser gir potensielt store valgmuligheter, med mulighet for utforskning av utdanning, kjærlighetsrelasjoner, identitet, yrkesliv og livsform.

Unge i dag har større valgmuligheter enn tidligere generasjoner. Dette gir dem samtidig større ansvar for egne liv. Boken handler om utfordringene knyttet til denne perioden. Gjennom 12 kapitler belyser samfunnsvitenskapelige forskere hvordan sosial bakgrunn, kjønn og individuell sårbarhet har betydning for valgmulighetene og risikoen for å falle utenfor i utdanningssystemet, arbeidsmarkedet, i sosiale relasjoner og med hensyn til familieetablering. Det stilles spørsmål om vi går mot et polarisert samfunn, der gapet mellom de som står utenfor og de som står innenfor blir stadig større.

Temaene er blant annet betydningen av utdanning, psykisk helse, rus, kontakt med barnevernet og sosiale relasjoner. Kapitlene kan leses uavhengig av hverandre og krever ingen spesiell forkunnskap om samfunnsvitenskap eller forskning. Målgruppen er studenter, forskere og klinikere som arbeider med unge og unge voksne. Boken anbefales spesielt til dem som jobber med utforming av tiltak blant ungdom og unge voksne som står i fare for å falle utenfor samfunnet.

\section{Ruth-Kari Ramleth}

Nasjonalt senter for selvmordsforskning og -forebygging Oslo 